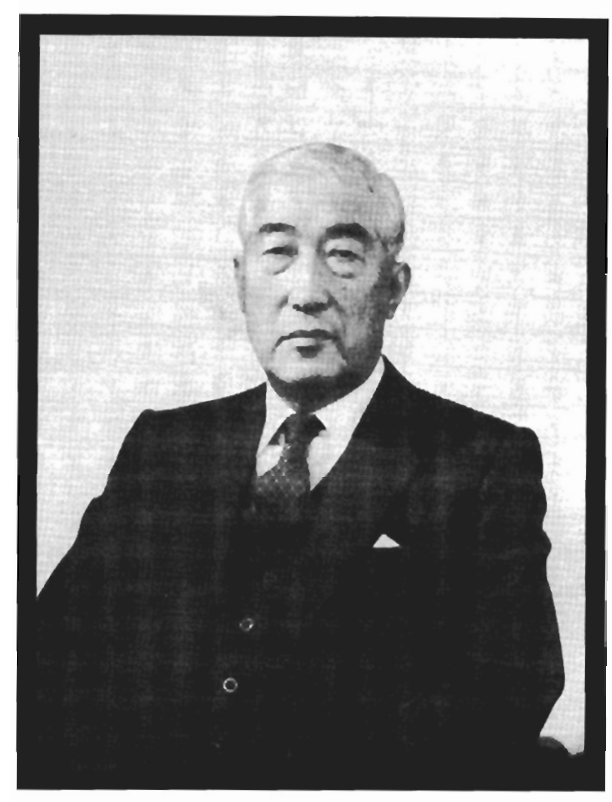

\title{
中島 稔先生を悼む
}

本学会名誉会員の中島稔先生が, 去る 8 月 26 日に亡くなられた. 享年 86 歳であった.

先生は戦時中の昭和 16 年に京都大学をご卒業, 直ちに助手に任ぜられ，教育・研究者としての一歩を踏みだされた。 以 来, 昭和 56 年に定年退官されるまで 40 年間にわたり, 誠実で包容力に富むご人格と, 堅実で体系的な学風をむって, 多 くの有為の人材を育成されるとともに，天然物化学から農薬化学におよぶ広範な分野で輝かしい業績をあげられた，先生 の主要な研究課題は, まず, はなひりのきの有効成分グラヤノトキシンの構造決定, ロテノイドの全合成, BHCの化学 的研究の途中で単離・発見されたベンゼングリコールから出発する環状糖アルコールの系統的合成，アミノ配糖体抗生物 質カナマイシン・カスガマイシンの全合成などの天然生理活性物質の研究である。第二には $\gamma$-BHCの工業的製造法之分析 法, BHC 異性体の立体化学, $\gamma$-BHC 類縁化合物の合成, $\gamma$-BHC および関連化合物の代謝・作用機構・構造活性相関など BHC を中心とした化学と生化学があげられる。第三は種々の殺虫剤すなわちカーバメート系化合物の抗アセチルコリン エステラーゼ活性，ピレスロイド系化合物の神経生理活性，ベンゾイルフェニルウレア類の表皮形成阻害活性などの活性 発現における分子機構と構造活性相関の研究に分類される。これらのうち特に環状糖アルコールおよびアミノ配糖体抗生 物質の合成研究が対象となり，昭和 40 年度日本農学賞および昭和 45 年度日本学士院賞をお受けになった。 また定年退官 された直後の昭和 56 年 8 月には上に記した先生の数々の研究業績が一括して対象となり, 1980 年度アメリカ化学会 Burdick and Jackson 農薬化学研究国際賞を受賞された。先生は教育・研究の傍ら，別に記されているご経歴にもあるとお り, 京都大学農学部長や文部省視学官, 日本農芸化学会会長や日本学術会議会員, 多くの国際学術会議の組織委員や委員 長などの要職を歴任され, 教育行政および学術振興に対し大いに貢献された。 以上の功績によって，昭和 59 年 11 月に文 部大臣表彰, 平成 2 年 11 月には勲二等旭日重光章を受けられている.

筆者は，大学卒業後同じく武居三吉先生をルーツとする三井哲夫先生の農産製造学研究室で研究生活を開始した。 その ころから中島先生には先輩として公私にわたっていろいろ面倒を見て頂いていた. 昭和 20 年代の終わり頃, 粗製 BHC 中の殺虫活性本体である $\gamma$ 異性体の含量を高めるために, ベンゼンの塩素化反応の条件の検討と $\gamma$ 異性体のポーラログラ フによる定量に, 実験室を“奔走” されていた助教授時代の先生, またそれに続いて昭和 30 年代初期, ベンゼングリコー ルを原料としてイノシトールなどのサイクリトール類をきわめて論理的・系統的に合成展開しておられたときの先生ご自 身の綺麗なフラスコさ代きなどは，いまだに印象鮮やかである.そして昭和 41 年に中島先生のもとに移籍することとなっ た. 以来僌しいながらも温情に富む数々のご指導をいただいてきた.

先生の傍らで過ごした現役時代，いろいろなことが思い出される．昭和 41 年，日光の金谷ホテルで第一回日米農薬科 学シンポジゥムが開かれた。これは筆者によってはじめて先生のお供をした国際会議であった。そして，その後日本農薬 学会の要職を務められることとなる先輩の先生方や，アメリカから参加された Casida 先生や Fukuto 先生などに，中島先 生から紹介して頂いたのがこの会議である. 当時「農薬」は現在のゲノム科学やナノテクノロジーに匹敵するほよ゙重要視 されており, 数少ない日米科学協力研究分野の一つに取り上げられていた. 参加者全員肪生き生きとして自信に満ちあふ 
れていたのを記憶している．先生はこの第一回のシンポジゥムの前に Berkeleyでひらかれた日米合同委員会の段階から 関与して抢られ，そののち八ワイで開かれた第 2 回日米シンポジゥムの日本側組織委員長を務められた。 そしてさらに昭 和 57 年 8 月に京都で開かれた国際純正応用化学連合 (IUPAC) 第 5 回国際農薬化学会議の組織委員長を務められること となる．この国際会議を日本で開くことが，本農薬学会設立の目的の一つでもあったのであるが，先生は，開催の 2 年前, 昭和 55 年度から多忙な取りまとめ役に献身された. 多数の有能な組織委員の協力の下, 会議は大成功裡に運営され, 各 国の農薬科学者の絶賛を博した。会議が終了し後始末が一段落したあとの慰労会で, 先生が下座に回られ, 組織委員全員 の前で正座の上，鄭重なお礼の挨拶をされたのが印象に残っている.

大学紛争の絶頂期から収拾期であった昭和 44 年 12 月からの 2 年間, 先生は京都大学農学部長としての任にあたられた。 この難しい時代の思い出をご自身が京都大学農学部七十年史の中で次のように述べておられる。「学部内に生まれつつあっ た相互不信感をとり除くことが先決であると思い，何事によらず率直に誠実な態度で対処することを心に決めた.」先生 はこのように終始誠実な態度を貫かれ，学問の府の “再建”に貢献された。この誠実という言葉とともに，先生が筆者に 語られた数多くのことのなかで，強く頭の中に残っているのは「己の分を知ること」である，筆者は長い間ずっとこれに 「こだわり」続けて抢り，先生から授かった銘上して今後む大切にしたいと考えている。一昨年平成 13 年の 12 月には， 京都新京極に近い筆者の仕事場においで頂き，楽しく昔話をしたのがつい先日のように思われる. 今年の 1 月には電話で お元気なお声を聞いていたし，8月上旬にあご家族から歳相応ながら元気にされていると同っていただけに，突然の訃報 は全く思い屯よらないことであった。たとえ天寿とあいえる捕齢であるとしても，先生にはもっと長生きして頂きたかっ た．先生のあの生粋の京言葉と恰幅のよい㧍姿に接することができなくなったことは，まことに残念であり寂しいかぎり である，先生のご冥福を心から祈るものである.

藤 田 稔 夫

中島 稔 先生 ご略歴

昭和 16 年 12 月 京都帝国大学農学部農林化学科卒業

昭和 17 年 4 月 京都帝国大学助手

昭和 22 年 11 月 京都大学助教授

昭和 28 年 6 月 農学博士の学位授与

昭和 34 年 1 月 京都大学教授 農学部農薬化学講座担任

昭和 37 年 12 月 農林省農業資材審議会委員（昭和 47 年 8 月 まで)

昭和 38 年 4 月 京都大学農学部付属農薬研究施設長（昭和 40 年 3 月まで)

昭和 44 年 12 月 京都大学農学部長・京都大学評議員（昭和 46 年 12 月まで)

昭和 46 年 2 月 文部省学術審議会専門委員（昭和 47 年 12 月 まで)

昭和 48 年 4 月 日本農芸化学会関西支部長（昭和 50 年 3 月 まで)

昭和 48 年 7 月 文部省大学設置審議会専門委員（昭和 55 年 3 月まで）

昭和 49 年 4 月 文部省農学視学委員（昭和 56 年 3 月まで）
昭和 51 年 4 月

昭和 52 年 4 月

昭和 52 年 12 月

昭和 55 年 2 月

昭和 55 年 4 月

昭和 56 年 4 月

昭和 60 年 4 月

昭和 40 年 4 月

昭和 45 年 5 月

昭和 56 年 8 月

昭和 59 年 11 月 平成 2 年 11 月
京都大学農学部付属農薬研究施設長 (昭和 53 年 3 月まで)

日本農芸化学会副会長（昭和 54 年 3 月まで） 日本学術会議会員（昭和 55 年 11 月まで）

文部省学術審議会専門委員（昭和 56 年 3 月 まで)

IUPAC 第 5 回国際農薬化学会議組織委員長 (昭和 57 年 12 月まで)

京都大学教授 定年退官, 京都大学名誉教授 日本農芸化学会会長（昭和 62 年 3 月まで）

日本農学賞

日本学士院賞

アメリカ化学会 Burdick and Jackson 農薬化学 研究国際賞

文部大臣表彰

勲二等旭日重光章 